This is the accepted version of a forthcoming article that will be published by Sage in European Journal of International Relations: http://journals.sagepub.com/loi/ejta

Accepted version downloaded from SOAS Research Online:

\title{
Deep Theorizing in International Relations
}

Felix Berenskoetter, Department of Politics and International Studies, SOAS University of London

fb12@soas.ac.uk

\begin{abstract}
This paper starts from the observation that, at a time when the popularity of grand theory is in decline among IR scholars, they do not agree on what they mean by theory. In fact, the celebration of theoretical pluralism is accompanied by the relative absence of a serious conversation about what 'theory' is, could, or should be. Taking the view that we need such a conversation, this puts forward the notion of 'deep theorizing'. Countering both the shallow theorizing of modern scholarship that conflates theory with scientific method, and the postmodern view that abstract narratives must be deconstructed and rejected, it offers a reading of the parameters along which substantial theorizing proceeds. Specifically, it suggests that 'deep theorizing' is the conceptual effort of explaining (inter)action by developing a reading of drives/basic motivations and the ontology of its carrier through an account of the human condition, that is, a particular account of how the subject (the political actor) is positioned in social space and time. The paper illustrates the plausibility of this metatheoretical angle in a discussion of realist, liberal and postcolonial schools of thought.
\end{abstract}

This article explores practices of theorizing world politics to put forward a reading of what is called 'deep theorizing'. It starts from two observations. The first is that scholars of International Relations (IR) do not agree on what they mean by 'theory'. More than three decades after James Rosenau noted that "much of the writing [in the field] suffers from loose and ambiguous conceptions of theory" (Rosenau 1980), the editors of EJIR stated "there remains no agreement on what constitutes proper theory in IR" (Dunne et al. 2013: 14; also Burchill, 2001: 8). Instead, we are presented with different kinds and types of theories attesting pluralism not only in the sense of having an ever-growing number of theories but in the very meaning of theory (Zalewski 1996; Jorgensen 2010; Dunne et al. 2013). The second observation is that the proliferation of 'theories' goes hand in hand with the perceived decline of established 'isms'. If there is a consensus among IR scholars it seems to be dismissing 'grand theory' as suitable frameworks for generating meaningful insights and conversations 
This is the accepted version of a forthcoming article that will be published by Sage in European Journal of International Relations: http://journals.sagepub.com/loi/ejta

Accepted version downloaded from SOAS Research Online:

about world politics. ${ }^{1}$ Approaches like realism and liberalism, in particular, are seen as reified dinosaurs from a bygone era whose insights are at best inadequate and at worst dangerous. They are said to be unscientific and ideological, promote insular thinking and stand in the way to progress (Lake 2011). Instead, we are urged to trace 'processes' and 'mechanisms' at the micro-level, and to critically dismantle all paradigms and engage with the vernacular.

Breaking with paradigms and developing new ways of understanding world politics is important and keeps the field alive. But is a theory what you make of it? Are there features that make some theories - the process of theorizing - more substantial than others? Most scholars would probably answer 'no' and 'yes', but won't go further. When John Vasquez (1995) noted over twenty years ago that not everything that calls itself such is a theory, he echoed a familiar complaint voiced by the likes of Stanley Hoffmann (1959), Raymond Aron (1967), or Kenneth Waltz (1979) who in their days saw 'theory' as an over-used and abused term among IR scholars. This observation still holds. The celebration of theoretical pluralism is accompanied by the relative absence of a serious conversation about what 'theory' is, could, or should be. Of course, there are exceptions (Chernoff 2007; Waever 2009; Burchill and Linklater 2009; Dunne et al 2013; Weber 2015; Jahn 2016). But for the most part, IR scholars seem to be happy with typologies and vague definitions of theory that do not offend anyone.

The problem with letting many theoretical flowers bloom is that it can crowd out substance. More precisely, it risks leaving the playing field to powerful voices whose narrow understanding of and attitude towards theory reduce appreciation of and appetite for substantial theorizing. While I disagree with the view that the field of IR is witnessing a retreat from theory (Dunne et al. 2013; see Berenskoetter 2012), I think Guzzini (2013) is correct in noting that theorizing world politics is squeezed between the emphasis on 'practical knowledge' and the popularity of what Mearsheimer and Walt (2013) call 'simplistic hypothesis testing'. Adding to the squeeze are postmodern and historical approaches that meet in the view that abstract thinking is doing more harm than good. The result is an academic field in which 'theory' is used loosely, narrowly and dismissively at the same time, which reduces it to a technical tool in the service of policy and pays little attention to, or is unsure how to deal with, bold new attempts to theorize world politics (e.g., Booth 2007; Deudney 2007; Lebow 2008; Weber 2016). It also underestimates the power of grand theory. I do not think this state of affairs is to be welcomed. But how to counter the squeeze, that is, how to

\footnotetext{
${ }^{1}$ Tellingly, grand theory is not discussed in the most recent stock taking volume (Booth and Erskine,
} 2016). 
This is the accepted version of a forthcoming article that will be published by Sage in European Journal of International Relations: http://journals.sagepub.com/loi/ejta

Accepted version downloaded from SOAS Research Online:

regain an appreciation for substantial theorizing? Rather than denouncing grand theories, what do they capture and how to create alternatives?

This article tackles the issue on a meta-theoretical level. If theory is an overused term, we need to take a step back and try to develop a "clearer notion of what the theoretical enterprise entails" (Rosenau 1980: 21). Or, at least, we need to have a conversation about what makes for a substantive theory and, thus about the fundamental parameters along which theorizing proceeds. Offering a step in this direction, the article counters both the shallow theorizing of modern scholarship that conflates theory with scientific method, as well as the postmodern stance that abstraction and foundational claims must be rejected. Instead, it puts forward a reading of what accounts for theoretical depth. In a nutshell, it holds that deep theorizing is about developing a picture of political (inter)action and order through conceptions of drives (primary motivations) and the ontology of its carrier (the political actor), which are grounded in an account of the human condition - namely, an account of how the subject is positioned in social space and time. The article suggests that grand theories offer such a picture. Hence, the basic argument is that thinking 'grand' requires going 'deep'.

The attempt to carve out foundational parameters of theorizing world politics might appear presumptuous and seen as an unnecessary and problematic move to discipline thought. Such is neither the intention nor, hopefully, the character of this article. While deep theorizing, as understood here, endorses a sort of post-foundational foundationalism, the aim is not to come up with a blueprint for 'how to do theory', let alone to define orthodoxy. It recognizes that there is no Archimedian point from which to explain a complex and often contradictory world and that all theories offer positioned knowledge and, hence, are limited in scope and carry within them a particular bias. The effort here is to take seriously the reading of theories as 'perspectives', but also shares the ambition to carve out a space for dialogue between different paradigms based on the contention that they offer "different perspectives on the same...ontological issue" (Wight 1996: 294). Whereas some see this space created around a core concept like 'practices' and its empirical manifestations (Adler and Pouliot 2011: 11), or in the acceptance of an unobservable reality that can be grasped theoretically across subjectpositions (Wight 1996, 2016), this article takes a different approach: it highlights how theories embed particular conceptions of agents, their drives and (inter)actions in subjective readings of the human condition, that is, in particular answers to the general question of what is, or should be, our place in social space and time. It thus supports the call for closer attention to the human and its reflexive capacities in our theoretical constructs (Jacobi and FreybergInan 2015) and demonstrates that doing so allows us to reground, recast and reconceptualize grand theories as situated, political and dynamic. 
This is the accepted version of a forthcoming article that will be published by Sage in European Journal of International Relations: http://journals.sagepub.com/loi/ejta

Accepted version downloaded from SOAS Research Online:

The discussion proceeds in four steps. The first part establishes three elements of political theory, the interpretive, explanatory and the normative. The second part reviews the barriers both modern and postmodern stances have erected against the pursuit of substantive theorizing. The third part sketches my reading of deep theorizing as conceptually tying an account of primary motivations to the ontology of the actors and grounded in an understanding of its spatial and temporal situatedness. The fourth part illustrates the framework in a discussion of realist, liberal and postcolonial schools of thought.

\section{Re-Approaching Theory}

A sensible starting point for thinking about theory is to ask about its purpose, what we need it for. In basic terms, theories are abstract mental frameworks - Gedankenbilder, as Max Weber put it - assisting us with generating knowledge about the world and offering a general language across empirical areas of expertise. In doing so it shapes academic debates and the contours of the field. Yet our specific conception of, and attitude towards, theory is informed by what kind of knowledge we think we can and should obtain, i.e. what we consider useful, or valuable knowledge. So how theory is understood and used in an academic field is also a result of the power structures that shape the field's conception of useful knowledge. With that in mind, loosely following George Sabine (1969 [1931]), it is safe to say that all political theories - including grand theories of world politics - combine three elements: an interpretive, an explanatory, and a normative. Each of these alludes to a particular function of theory and is tied up with views of what is possible and useful knowledge. ${ }^{2}$

The interpretive (or heuristic) element enables us to see who and what is out there, what is happening, and to make sense of experiences and connect them to a meaningful picture of 'the world'. In the words of Hans Morgenthau (2011 [1954]: 266), theory enables us "to bring order and meaning to a mass of phenomena which without it would remain disconnected and unintelligible" (also Waltz 1979: 4ff). By giving us categories and concepts and by placing them in a relationship, theory works as a source of meaning and cognitive guidance. It makes the world intelligible by mitigating its complexity (there is too much 'stuff' to be grasped at once) and its ambiguity (the 'stuff' needs to be interpreted). It provides an ontology, which makes us see actors, structures, events, dynamics, and problems (Cox 1981), and it guides our formulation of important questions (Hoffman 1959: 348). Thus we often call theory a 'framework'. While some are satisfied with the heuristic function and relegate the discovery of causes to empirical research (Humphreys 2011), most scholars expect theory to provide not

\footnotetext{
${ }^{2}$ While a theory may highlight one element and downplay another, the suggestion that those elements describe different kinds of theory (Jorgensen 2010; also Dunne et al. 2013) is misleading, as it gives the impression that theories can have only one of those functions.
} 
This is the accepted version of a forthcoming article that will be published by Sage in European Journal of International Relations: http://journals.sagepub.com/loi/ejta

Accepted version downloaded from SOAS Research Online:

just concepts but to connect them into explanations and arguments, "statements of what may roughly be called a causal nature" (Sabine, 1969 [1931]: 12). In other words, theory has an explanatory function; it helps us understand how and why things happen. As Hume argued, experience cannot establish causes, we can only experience or observe conjunctions of A and B occurring together. Establishing why they occur together and how exactly A and B are related is a mental process, making cause "a human invention" (Lebow 2014: 1). In line with work encouraging IR scholars to broaden our conception of causation (Kurki 2008; Lebow 2014), the explanatory function is understood here as an abstract argument of why the certain (inter)action, events, dynamics, etc in our picture occur. As such, following Weber's (1992: 107f) point that Verstehen is a form of explaining, it also encompasses 'constitutive' theorizing (Wendt 1998; Lebow 2014).

Whereas the first two elements primarily serve an analytical purpose, the normative element highlights how theory guides thoughts and actions with the intent of improving our lives. It expresses the theorist's value-orientation and reveals that heuristic and explanatory functions are infused with subjective experiences, concerns and hopes. Catering to the human ambition to shape the future and make that world a better place, theorists raise questions and offer ideas with the hope to influence the course of events relevant to the socio-political context they care about. Theorists are not always transparent about this aspect, indeed they often hide their normative outlook as it stands in tension with the ambition to produce objective and 'scientific' scholarship. However, as a recent comprehensive attempt to bring the normative element back into the sight of the mainstream reminds "every international relations theory is simultaneously about what the world is like and about what it ought to be like" (Reus-Smit and Snidal 2008: 6; see also Smith, 2004; Levine 2012).

Containing all three elements, grand theories are "singing our world into existence" (Smith 2004) by providing 'big pictures' of a configuration of particular actors, their interactions with each other and within a particular socio-political order that governs their lives. They show how these interactions (should) lead to the emergence, maintenance and challenge of international order, which involves the exercise of power in both coercive and productive forms and, thus, politics. Importantly, in their analytical and normative function, grand theories are not sterile models divorced from concrete political concerns and struggles. ${ }^{3}$ Like all political theories, they are created in and mobilized to make sense of a particular sociopolitical context; often "secreted...in the interstices of political and social crisis" (Sabine

\footnotetext{
${ }^{3}$ This appears to have been the reading of C. Wright Mills, who is credited with coining the term 'grand theory' in his critique of functionalism (Brown 2013).
} 
This is the accepted version of a forthcoming article that will be published by Sage in European Journal of International Relations: http://journals.sagepub.com/loi/ejta

Accepted version downloaded from SOAS Research Online:

1969 [1931]: 3). Formed out of 'practical knowledge' and with the ambition to feed back into it (Morgenthau 2011 [1954]; Guzzini 2013; Mearsheimer and Walt 2013), they shape the worldviews of practitioners and are "politically relevant" (Jahn 2016: 9). Judgments about a theory's relevance depends on whether the world it depicts resonates with us. Yet, as Chris Brown (2013: 2) points out, "to qualify as 'Grand', a theory should...have implications beyond the immediate discourse within which it was created". Offering a picture that is global in scope and universal in appeal is arguably a desirable quality for theories seeking to capture world politics. And so, in their ambition to think big, grand theories (must) claim that their insights stretch beyond a particular geographical and historical context and touch on broader, more general 'truths' about the worlds built, experienced and imagined by humans.

The tension between seeing a theory embedded in a particular sociopolitical environment and expecting it to offer insights and arguments that transcend this context is well known. My way of negotiating this tension is to suggest that for a theory of world politics to qualify as 'grand' it also needs to be 'deep' by grounding its big picture of actors, (inter)actions and orders in answers to fundamental philosophical questions of where and who we are, or want to be, in social space and time. The answers are particular and depend on the theorists' position, which turns the pictures of world politics into perspectives. As such, the perspectives offered by grand theories might be incompatible, but the answers underpinning them are formulated along the same philosophical parameters, which provide the 'macrofoundations' of grand theories. ${ }^{4}$ Such a reading still allows a claim to universality, but it is a particular kind that "rejects the false and politically inspired dichotomy between universalism and relativism" (Acharya 2014: 649). Before engaging this, and to justify the effort, let us briefly review why both modern and postmodern stances - broadly speaking the two sides of the 'third debate' identified by Lapid (1989) - have come to distract or discourage IR scholars from thinking about theory in 'grand' terms and, thereby, also from deep theorizing.

\section{The Modern Move to Shallow Theory}

The assumption that humans have the ability to make world intelligible with the help of cognitively stable abstractions that assign domains and limits to 'things', that we can demarcate, order and accumulate causal knowledge about 'the world', and thereby learn to control and improve it - all that has a distinctly modern undertone. Even if theorists are aware that their ontological maps and explanations are more ideal types than mirror images of 'reality', the modern ambition/belief is that these can serve to accumulate ever more accurate knowledge about 'the world' in two ways. The rationalist approach emphasizes the human

\footnotetext{
${ }^{4}$ As opposed to the micro-foundations of 'middle range' theory (Lake 2013).
} 
This is the accepted version of a forthcoming article that will be published by Sage in European Journal of International Relations: http://journals.sagepub.com/loi/ejta

Accepted version downloaded from SOAS Research Online:

ability to reason and make logical, systematic and coherent connections in the mind (creating what is also termed 'pure theory'). Slightly different, the empiricist approach emphasizes the senses and holds that insights/arguments are abstracted from experience (creating 'empirical theory'). Thus, coherent and consistent logical reasoning makes the theory internally valid, whereas evidence that 'fits' establishes its external validity.

The modern ambition to progressively de-mystify the world regards theory as a scientific tool that needs to be continuously sharpened to improve our ontological map and explanations. This is done by 'applying' theories, a process in which the modern approach merges with positivism and pragmatically combines two strategies: testing the theory against 'reality' and against 'rival' theories. Through such testing, the strengths and weaknesses ('flaws') of a theory are revealed, and if it turns out to be weak one can either attempt to 'fix' the theory or discard it. The modern logic for evaluating the quality of a theory is thus quite simple: theories are either good (right/valid) or bad (wrong/invalid) depending on whether it can be supported by evidence - or 'verified' - and fares better than alternative 'rival' theories. This means theoretical knowledge is always relative; a theory is never good in and of itself but can only be better than others, which implies that the quality of a theory is generated and sustained through competition. Consequently, theories need to be designed in a way that allows such evaluation to take place. The focus on testing theory through empirical verification is complemented by Popper's emphasis on the need to produce propositions that can be 'falsified' by stating clearly what evidence would be needed to 'disprove' the proposition. ${ }^{5}$ This principle, combined with a commitment to parsimony, has been very popular among IR scholars and discouraged theorizing in a deeper sense by effectively reducing the meaning of theory to a simple causal statement, or hypothesis, of the kind 'if A then B'. Thus, in their treatise on research design King, Keohane and Verba could afford to hardly discuss theory. And when they mention it, theory is understood as an "interrelated set of causal hypotheses" (King et al., 1994: 99) with falsification as its most important 'property', culminating in the claim that "a 'theory' which cannot be wrong is not a theory" (King et al., 1994: 100). By declaring a logically falsifiable statement an "essential criteria" of theory (Vasquez 1995: 230) this stance has to either dismiss or ignore grand theories, which cannot be reduced to falsifiable hypotheses. ${ }^{6}$

\footnotetext{
5 Popper knew that theories cannot be falsified in the strict sense as no conclusive disproof can ever be produced empirically, but considered the principle a necessary critical check (Popper, 1968).

${ }^{6}$ Although some still feel compelled to pay lip service to falsifiability (Wendt 1999: 373). Also, this does not prevent attempts to derive hypotheses from grand theories.
} 
This is the accepted version of a forthcoming article that will be published by Sage in European Journal of International Relations: http://journals.sagepub.com/loi/ejta

Accepted version downloaded from SOAS Research Online:

As such, the modern stance happily operates with a shallow understanding of theory. ${ }^{7}$ Not only does it reduce concepts to variables and arguments to narrow causal statements, it fares poorly with regard to all three aforementioned elements of theory: it does not integrate the interpretive function into the task of theorizing but settles its ontology on the level of assumptions; it reduces the explanatory element to a simple 'If A then B' hypothesis; and it ignores the normative element of theorizing in the name of scientific credibility and the quest for objective truths. Moreover, the view that a theory is good only if it can be tested against rival theories and supported empirically shifts attention to method. Indeed, it invites scholars to conflate theory and method by confusing the task of identifying meaningful relationships through a philosophically grounded framework with the procedure of ever-more precise data collection. By cherishing research designs that place persuasive weight on clear hypotheses and the process of gathering empirical evidence, the scientific ambition created an academic environment where scholars supposedly talk about 'theory' but mean method (King et al. 1994; Shapiro et al. 2004). And more than three decades after Rosenau (1980) noted that the field of IR suffers from confusion between theory and method, this problem is more prevalent than ever (Mearsheimer and Walt 2013).

\section{The Postmodern Resistance to (Grand) Theory}

IR scholarship inspired by the 'post-modern' Zeitgeist and infused with a critical stance, often under the label of 'post-structuralism', marks the other end of the spectrum. ${ }^{8}$ As the 'post' indicates, its views on the purpose and possibility of knowledge go 'beyond' the modern position. It sees modern thought in crisis, as relying on categories unable to make sense of the world we find ourselves in, and critical about the project of modernity more generally (Brown 1994). In contrast to the modern ambition to reduce complexity, ambiguity and contradiction, a postmodern stance embraces these features. Rather than seeking coherence and logical unity of thought, it emphasises the incoherence and fragmentation of knowledge; and so rather than asking theorists to generalize, connect and order the world into a harmonious whole it asks them to accept that the world is particular, disjointed and disorderly (Der Derian and Shapiro 1989; Rosenau 1992). This postmodern position rests on a reading of the subject and its capacities as complex and lacking unity, as "unsettled" (Edkins 1999; Lyotard 1984: 15), and as embedded in multiple social relationships that are "more complex and mobile than ever before" (Ibid; see also Luhmann 1992). Because there is no unifying subject that can assign

\footnotetext{
${ }^{7}$ See also Smith (1996). I adopt the terms 'shallow' and 'deep' theory from Nicholson (1996: 136).

${ }^{8}$ Labeling all 'poststructuralist' scholarship 'postmodern' is problematic, yet the merger is common enough in the IR literature. For calls to differentiate between the two, see Campbell (2007: 211) and Brown (1994: 2).
} 
This is the accepted version of a forthcoming article that will be published by Sage in European Journal of International Relations: http://journals.sagepub.com/loi/ejta

Accepted version downloaded from SOAS Research Online:

coherence to the world and because of the world's every increasing complexity - because the knowing subject and the object of knowledge both 'disappear' - we cannot possibly gain that cognitive stability and guidance modern theorists strive for.

This view about impossibility of solid epistemological foundations has significant implications for the approach to theory. It harbours a suspicion of the interpretive and explanatory function and rejects how they are practiced in modern theorizing, not least due to the latter's downplaying, if not denial, of the normative and subjective element. In IR, this merges with a critical stance of trying to expose, expand and escape from the crisis of the modern project. That is, the post-modern stance on knowledge is (uneasily) combined with critical theory's emphasis on emancipation: rather than seeking control of nature, the primary purpose of knowledge is (to enable) emancipation by "identifying and eradicating unnecessary social confinements and constraints" (Linklater 1996: 281). Theories are seen as such constraints: abstract reifications that blend out and 'forget' their positioned and subjective nature (Cox 1981). The issue is not merely cognitive bias. Theories are criticised as meta-narratives that impose particular worldviews and advance political projects hidden behind a claim to nature and reason; as ideologies based on myths attempting to turn cultural particularities into universal truths (Weber 2010: 6f; see also Walker 1989, Levine 2012). Consequently, the task is to demystify theories as neutral instruments of scientific research, to deconstruct their reified ontology and simple explanatory logics and expose them as sociopolitical constructs. This not only involves critical engagement with causal claims, concepts and categories, but also with the language, style and format in which theory appears, that is, the aesthetic of theoretical representation (Bleiker 2009).

Given its anti-foundationalism and emancipatory stance we might say, with Paul Du Man (1982), that the post-modern position inhabits a Resistance to Theory expressed in two ways. First, it involves digging up and deconstructing foundational claims. Drawing on heuristic frameworks developed by Foucault, Derrida and other postmodern icons in continental philosophy, this scholarship can be very skilful in scrutinizing theories and problematising their assumptions, concepts and logic through a method of deconstruction and immanent critique (Zehfuss 2002; Burke 2008; Arfi 2012). Yet while sharpening our eye for the sociopolitical parameters of a theory and tracing its foundational claims, the postmodern approach asks also us not to accept these foundations and the theoretical house built on it. Thus, the call for liberation from modern orthodoxy goes hand in hand with, second, the call to resist and reject abstract representation of the world for analytical purposes in order to keep an open mind. Its proponents are convinced of the impossibility of grand theory (Behnke 2001) and ask us to "forget IR Theory" (Bleiker 1997). Rather than creating or buying into abstract 
This is the accepted version of a forthcoming article that will be published by Sage in European Journal of International Relations: http://journals.sagepub.com/loi/ejta

Accepted version downloaded from SOAS Research Online:

representations, it seeks to show what is left out and brushed over in modern designs by retrieving silences and embracing aporia through historical genealogies and by tracing subaltern realities through ethnography and more playful methods such as poetry (Bleiker 1997; 2009) or collage (Sylvester 2009). In short, it seeks out a contingent, complex and incoherent reality unvarnished by theory.

These two intellectual positions - the first dominant in the United States and the second more prominent in Europe - offer very different approaches to theorizing. They ground their respective conception of and attitude towards theory in a particular reading of the nature of the human subject and its abilities, intertwined with a particular reading on the kind of knowledge humans can or should produce. This leads the modern scholar to employ a shallow conception of theory, whereas for the post-modern scholar it requires the rejection of (grand) theory. Both end up with methods. What is left behind is a constructive engagement with and appreciation for efforts to substantially theorize world politics. The following is an attempt to recover this position.

\section{Recovering Deep Theorizing: Thinking Through the Subject and its Drives}

The use of the term 'theorizing' indicates that theory is treated here not as a static map or model but as a thought process. Although this is often hidden when the result is presented in writing, few theorists would claim to have created or to be working with a complete and motionless framework. A theory is always an incomplete train of thought and, hence, it makes more sense to speak of theorizing as an open-ended process: a rich, dynamic and creative undertaking of weaving conceptual webs that are open and malleable rather than fixed and firm, with arguments developed rather than simply stated. Experience, positionality and logic play an important role in this process, which is never free of tensions, giving room to criticism and disagreement and allowing 'the theory' to adapt and evolve.

With that in mind, grand theories of world politics are understood here as amalgams of theories of action and of order. They depict a particular world of actors whose (inter)actions make possible the emergence, maintenance and challenge of (international) order. In this picture, the ontology of actors and their drives and, through them, conceptions of agency are of central importance. While IR theories are often sees as foregrounding structures and systems, it is drives turn the subject into an actor "capable (at least in principle) of critically evaluating and reconstructing the conditions of their own lives" (Emirbayer and Mische 1998: 964) and, thus, of initiating and engaging in (inter)action. There is no agency without that "internal spring to action (Boucher 1998: 13). For a long time the question "what moves man" (Freyberg-Inan 2004) was answered with reference to the concept of 'interest' as the preferred 
This is the accepted version of a forthcoming article that will be published by Sage in European Journal of International Relations: http://journals.sagepub.com/loi/ejta

Accepted version downloaded from SOAS Research Online:

heuristic shortcut (Hirschman 1986; Kratochwil 1982). Some have offered theoretically sophisticated explorations of how 'interests' are formed and/or have sorted through different kinds and types of motivational forces, like needs, desires, intentions or preferences (Wolfers 1962; Kratochwil 1982, Finnemore 1996; Frieden 1999; Lebow 2008). It is much more common however to treat the concept in simple and uncomplicated ways. After dutifully acknowledging that humans harbor a multitude of 'interests', theories tend to single out one or two which are presented as assumptions or subtly woven into the theory. The same goes for the ontology of the political subject/actor embodying these drives. Yet as interventions by feminist scholars and participants in the structure/agency debate have long shown, IR theories constitute their actors, complemented more recently by work exploring links between drives and actor ontology on a cognitive, psychological, neurological and emotional level (Wendt 1999, 2003; Freyberg-Inan 2004; Lebow 2008; Epstein 2013; Hutchison and Bleiker 2014). The impression that theorists pick pre-formed actors with innate drives from the world stage, upheld by declaring them part of the theory's unalterable "hard core" (Lakatos 1970), may be convenient for stylizing a theory into a stable model. But it only conceals the thought process bringing them to life.

The approach here thus sees drives and the ontology of actor(s) as constructed together and suggests that carving out their form(s) and relationship(s) is an integral part of deep theorizing. My entry point for thinking more carefully about this process is Steve Smith's call that scholars should pay more attention to "the viewpoint of the actors" (Smith 2004: 511). On the back of his observation that most IR theories deduct motivations and behavior of agents from a structural logic, ${ }^{9}$ Smith asks theorists to tell stories about action and order through the eyes of the subject(s), which necessarily includes acknowledging that theory is written "with a view from somewhere" (Smith 2004: 514). Taking the 'inside' perspective, he suggests, provides a better understanding of the kind of structures that matter to actors, and it improves our conceptualization of agents and the motivation(s) behind their action. Reminiscent of calls for standpoint theory made in feminist scholarship (Harding 1993), Smith effectively directs attention to an epistemological perspectivism in theorizing that thinks ontology and drives with, or through, the subject. In line with recent calls to take a careful look at the human element in theorizing the international (Jacobi and Freyberg Inan 2015), this is the approach probed here. Given that actors in world politics usually - but not necessarily - take the form of human collectives, theorizing through the subject raises the issue of anthropomorphism. Reading 'the subject' as a collective Gestalt can be justified by noting that cognitive, linguistic, moral, and affective capacities of humans are intertwined

\footnotetext{
${ }^{9}$ This is already visible in Wendt (1987). See also Doty (1997). Even in Wight's (2006) sophisticated conceptualization, agents are largely made up of structures.
} 
This is the accepted version of a forthcoming article that will be published by Sage in European Journal of International Relations: http://journals.sagepub.com/loi/ejta

Accepted version downloaded from SOAS Research Online:

with and find expression on the social level. At the same time, IR theorists may well be guilty of anthropomorphism. That is, we may have to accept that the theorist's own positionality and experience not only influences how they depict actors and but also tempts them to treat collective actors as if they are 'persons'.

\section{Rediscovering the Human Condition: Situatedness in Space and Time}

What, then, are the parameters along which deep theorizing proceeds? The basic claim here is that actor ontology/ies and their drives/basic motivations, which spur (inter)action along a spectrum from conflict to cooperation, are developed through an account of the human condition. This is different from anchoring ontologies and drives in human nature. The latter designates a quasi-essentialist understanding of properties and drives shared by all humans; it purports to know what and who the actors 'naturally' are and what they want, and in doing so provides analysts with a universal baseline for explaining behavior regardless of context. ${ }^{10}$ As such, references to human nature allow theorists to fix ontology and 'interests' qua assumption. By contrast, a human condition approach is concerned with delineating the environment that self-conscious/reflexive humans find themselves in and with exploring how their engagement with this environment influences behavior (Harvey, 1989). To be sure, accounts of the human condition are not entirely free of understandings of human nature. For instance, the biological fact that the human body is made up largely of water is linked to the need to consume water, and so humans need to live with access to water. Yet as our biological system also needs oxygen we cannot survive in water without the assistance of machines, so we usually find humans living on land, making earth "the very quintessence of the human condition" (Arendt 1958: 2). And to ask how humans perceive their environment requires senses that perceive and a mind that processes those perceptions. Indeed, the clearest sign of a 'human nature' element in the approach presented here is the Kantian view that, as conscious and reflexive beings, humans try to make sense of their environment and of themselves within it. It accepts the need for orientation - to make sense of, and ones' situatedness in, 'the world' - and, thus, accepts the "impossibility of perspectiveless thinking" (in Hutchings 2011: xx). The line between assumptions about human nature and accounts of the human condition is thus blurry. And yet, the distinction is important because their respective implications for and demands of theorizing are quite different (Arendt 1958: 9f.).

On its own, the need for orientation does not tell us anything about the form of the actor or its possible actions. For that we need an account of the human condition that shows the ontology

\footnotetext{
${ }^{10}$ On human nature assumptions in IR theory, see Doyle (1997); Freyberg Inan (2004); Symposium on 'The Return of Human Nature in IR Theory' in the Journal of International Relations and Development vol. 9, no. 3 (2006); Brown (2009); Crawford (2009); Jacobi and Freyberg Inan (2015).
} 
This is the accepted version of a forthcoming article that will be published by Sage in European Journal of International Relations: http://journals.sagepub.com/loi/ejta

Accepted version downloaded from SOAS Research Online:

of the subject/actor as part of a configuration in which certain drives and (inter)actions become possible and pertinent in the first place. Establishing a theoretical link between the ontology of actors, their drives and the environments they are situated also identifies a particular set of problems or challenges that actors face (Cox 1981). As such, importantly, an account of the human condition is not a discrete thing that can be theorized on its own. It is part of the subject/actor as much as the subject/actor is a part of 'it'. As Arendt (1958) lays out in her discussion of particular conditions and human activities, we cannot meaningfully conceptualize the condition separate from the subject and its drives. They are existentially intertwined and unfold together. In Arendt's words "men are conditioned beings because everything they come in contact with turns immediately into a condition of their existence" (Arendt 1958: 9). As such, humans not only experience and try to make sense of their condition and their place within it, they also have the power to shape it. In fact, Arendt suggests, the condition is "self-made to a considerable extent" (Arendt, 1958: 10, 9).

It is common to read the human condition as having three general dimensions: the social, the spatial and the temporal and to see humans as existentially intertwined with all three. IR scholars pay automatic attention to the social dimension, as humans (groups) situated in a social environment (populated by other groups) gives rise to (international) politics in the first place. Yet the world that humans - as individuals or collectives - relate to, and within and towards which they act is not just social but also temporal and spatial. And, in fact, most theories of world politics do offer accounts of how political relations are intertwined with and shaped by particular conceptions of space and time - through geography, borders and bridges, and readings of past, present and future. When those dimensions became submerged by attempts of 'naturalizing' political space (Agnew 1994) and 'de-temporalizing' social scientific arguments (McIntosh 2015) critical scholars made them explicit again. Among others, Rob Walker repeatedly reminded that theories of international relations are "spatial framings of political life" (Walker 1995: 309; see also van Houtum et al. 2005; Branch 2014), and Kim Hutchings (2008) masterfully exposed the temporal orientation of IR theories (see also McIntosh 2015; Hom et al 2016). Before illustrating how concrete expressions of these dimensions are woven into grand theories, let us review how deep theorizing covers the three functions of theory noted at the outset.

Describing the contours of social space and time in which political subjects move, and developing their ontology, drives and interactions through and with this environment is an interpretive act. As a process of constitutive theorizing, it also is explanatory. In fact, it is compatible with a causal account broadly understood "since, by definition, motives are always prior to the action and can thus be considered its antecedent conditions" (Kratochwil, 
This is the accepted version of a forthcoming article that will be published by Sage in European Journal of International Relations: http://journals.sagepub.com/loi/ejta

Accepted version downloaded from SOAS Research Online:

1989: 24f). Extending the causal story in this way is engaging in "deep causality" (Onuf, 1989). This does not lead to holistic explanations, however. Theorizing through the subject requires taking seriously the Kantian insight that conceptions of space and time are not objective recordings of an external reality but transcendental conditions of sensible experience, represented through the human mind (Hutchings 2008: 3). This has implications for a theory's analytical scope. Because not all humans experience, conceive of and respond to their socio-spatial and socio-temporal condition in the same way, different theories offer different accounts. Each shows a particular condition in which particular actors with particular drives deal with their place in space and time, which structures relationships and (inter)actions. In doing so, each effort at deep theorizing puts forward a unique reading of the nature and location of world politics.

And since creating a frame that orders social space and time is a powerful way of governing political communities (see Berenskoetter 2014), developing a theory through such a frame is also political. It is expressed normatively in advancing a particular reading of the human condition and giving the actor a sense of what is 'right' or 'wrong' with it, expressed in ideas of how to maintain, improve, or challenge the condition. That is, deep theorizing not only asks of the theorist to "apply imagination and maintain philosophical discipline" (Rosenau 1980: 21), it also recognizes that the theorists' own situatedness echoes in the account. It accepts that "all theories have a perspective [derived] from a position in time and space" (Cox 1981: 128) and that this position influences how time and space - and agency within it - are theorized. We theorize about a world we know and identify with, or against, which is expressed in the attitude towards the condition described, its desirability and the possibilities it holds for being and for action: some might see the condition as undesirable but inescapable and theorize about the ways political actors can adjust and make the best of it; others may display a positive attitude towards their portrait of the human condition and see it in perhaps imperfect but potentially favorable terms; and a third account may find the condition deeply problematic and seek ways to transform or escape it altogether.

\section{Deep Theorizing in IR: Three Examples}

Taken together, then, deep theorizing is concerned with how political actors view and organize their situatedness in (social) space and time, how they shape and are shaped by their spatio-temporal reality, and how they work with or against this condition through particular forms of (inter)action. This is illustrated here through three schools of thought: realism, liberalism and postcolonialism. Treating them as schools of thought assumes the existence of communities of knowledge formed by like-minded theorists and involves clustering and 
This is the accepted version of a forthcoming article that will be published by Sage in European Journal of International Relations: http://journals.sagepub.com/loi/ejta

Accepted version downloaded from SOAS Research Online:

combining their insights into a comprehensive and necessarily stylized train of thought. ${ }^{11}$ The three schools are chosen because they offer influential and distinct perspectives on international politics; they are, as Brown (2013: 493) would want it, "world-revealing". Despite their alleged decline, realism and liberalism still are the heavy weights of mainstream theorizing in IR. Also described as forming a rationalist paradigm (Keohane 1988), they (partly) build on the social contract philosophies of Hobbes, Locke, Rousseau or Kant, whose 'state of nature' images are among the most prominent accounts of the human condition in Western thought (Kersting, 1996; Doyle 1997). Yet realism and liberalism also have been exposed as Eurocentric, shaped by Western experiences of two World Wars, the Cold War and its aftermath, and as undergirded by "racist latticework" (Henderson 2013: 90). ${ }^{12}$ Postcolonialism presents an alternative, or "antidote" (Hobson 2012) to them precisely because it grows out of a critique of Eurocentrism and offers perspectives from the 'nonWest' that are ignored by realist and liberal theorists. By reading the world from the position of the 'subaltern'/the Global South, this school is able to provide "alternative accounts of subjecthood" (Sabaratnam 2011: 786) that focus on the experiences of and struggles against colonial practices.

While postcolonialism thus goes some way in balancing IR's conversations about world politics, using it as the third example here is not uncontroversial. Representatives of this approach tend to be highly critical of IR theories per se, which are seen as variations of European/Anglo-American worldviews and part of the imperial structure that postcolonial thought must resist, contest and escape from. As such, postcolonial scholars prefer to pursue an agenda of "situated critique" (Epstein 2014) that seeks to dismantle a system of thought that oppresses, marginalizes and silences subaltern experiences and voices (see also Sabaratnam 2011; Seth 2013). They hold that these experiences cannot be captured in abstract frameworks, not least because every postcolonial configuration is different and the general tone and universal pretense of theory are precisely what deprives the subaltern of a voice. While this stance has its merits, here I side with the view that a postcolonial perspective can be expressed theoretically and that it is possible to theorize the postcolonial subject/actor (Bhabha 1994; Jabri 2013; also Gandhi 1998). The tricky question remains how such experiences and voices can be theorized and who can legitimately do so without relying on "high European theory" (Young 2001: 67) and falling back into an elite Western mindset. Thus, my attempt to show parallels with prominent Western theories and to suggest that the

\footnotetext{
${ }^{11}$ In Jorgensen's typology (2010), I discuss 'traditions' and draw on various 'currents' within each. Kuhn's (1996) 'paradigm' and Lakatos' (1970) 'research programme' also designate something similar.

${ }^{12}$ On the latter point see also Vitalis (2015)
} 
This is the accepted version of a forthcoming article that will be published by Sage in European Journal of International Relations: http://journals.sagepub.com/loi/ejta

Accepted version downloaded from SOAS Research Online:

postcolonial condition/subject can be captured within the parameters of deep theorizing outlined earlier may come across as "gentrification" (Weber 2015). Still it is a worthwhile effort, not least because it presents postcolonialism as a substantial and important theoretical alternative to realism and liberalism. Whether the parameters for doing so are Eurocentric and, even if they are, whether that disqualifies them from contributing to an informed debate about postcolonial theorizing, is for the reader to judge.

\section{Realism}

Echoing Hobbes' emphasis on the individual's will for self-preservation, realists emphasize survival as the most basic drive (Herz 1959: 3). While one may be tempted reduce this to an instinct, the meaning of survival is logically tied to an account of what is to be preserved/secured. Realist ontology is one of 'groupism', that is, it views humanity as divided into distinct groups (Wohlforth 2008). This partly stems from experiencing the pervasive power of nationalism to form groups with distinct and exclusive territorial and historical claims and corresponding demands for self-determination, or sovereignty. The political entity set up to meet this demand is the state. Being sovereign is thus not a given but something people want and expect the state to be. It is an expectation the state must fulfill to justify its existence and, as such, a basic motivation tied to the ontology of the realist subject-actor. The shift from 'the group' to 'the state' as the primary actor and, correspondingly, to state survival as the drive, is usually brushed over in realist theorizing by treating the two as congruent. While this is problematic, realists shift the focus to how the state co-exists with other states and to develop their core features, concerns and interactions through a particular reading of their spatial and temporal situatedness.

The demand to be(come) sovereign and the inside/outside logic this entails is expressed in spatial terms by reducing the state to a distinct territorial space defined through its separation from other states by a material border as the defining feature. In short, for realists, sovereignty means having control over a particular territory (Morgenthau 1960: 312; Mearsheimer 2001: 31). The compartmentalization of the world into territorial units is upheld through mutual recognition of the border, which thus is a feature not just of separation but also of connectedness. Realists package this socio-spatial dimension of the human condition into the image of the state system as an anarchical environment, described by Waltz (1979: 74ff., 118) as a constitutive force that "molds" and "causes" states to be "alike" by encouraging "similarities of attributes". Blending sociological, microeconomic and Darwinian logic and two corresponding mechanisms, socialization and competitive selection, states are expected to either adjust or disappear. Locating the constitutive force in the international system and portraying states as "passive-adaptive" actors (Hobson 2000) is problematic as the anarchical 
This is the accepted version of a forthcoming article that will be published by Sage in European Journal of International Relations: http://journals.sagepub.com/loi/ejta

Accepted version downloaded from SOAS Research Online:

character of the system is logically dependent on the ontology of states as sovereign/seeking sovereignty. Because realists are not very good in discussing this co-constitutive relationship between actor ontology (states) and the socio-spatial environment (anarchy), they have been accused of circular reasoning (Wendt 1987, 1999).

Although some trace how the system "will push the range of governmental functions towards sovereignty" (Buzan et al., 1993: 39), realist theorizing usually absorbs the concern with 'sovereignty' into 'power' as the dominant concept for both state ontology and basic motivations. The drive for power is developed through an account of the socio-temporal dimension, which links the will to survival to two emotional drives, namely fear and distrust. When realists invoke Hobbes to suggest that states in an anarchical system live in "continual fear and danger of violent death" (Hobbes in Doyle 1997: 114), the absence of a third party arbiter as such does not generate this fear. Rather, it is generated by uncertainty about what others might do, which strictly speaking involves two kinds of uncertainty: the impossibility of knowing the intentions of others and the impossibility of knowing the future. The first applies the problem of other minds to the collective level, as sovereign states do not easily share their plans and intentions with others. Intrinsic to the socio-spatial ontology of states as separate and 'closed off' entities is the difficulty for outsiders to 'see' and understand what goes on inside. The second, temporal uncertainty, is of even greater significance. A core aspect of realist logic is the depiction of states as temporal beings worrying about an uncertain future: regardless of what the interests of state $\mathrm{Y}$ are today, even in an environment of perfect information state $\mathrm{X}$ cannot know what $\mathrm{Y}$ 's interests will be tomorrow and, consequently, what it might do. So because the future is unknown/contingent, the intentions of other states are also unknown/contingent.

Crucially, realists argue that states (should) respond to this condition with distrust and pessimism, that is, with a worst-case scenario based on the possibility that the future intentions of others might be hostile. As captured in Herz's famous notion of the security dilemma, distrust is a rational answer to uncertainty. However the realist actor also fills the unknown future with historical knowledge. While there are disagreements between 'offensive' and 'defensive' realists about what knowledge should be used to ensure a secure future (Taliaferro 2000), the overriding view is that war forever "lurks in the background" (Carr 2001 [1946]: 102). Adopting Hobbes' view that the 'state of nature' is a 'state of war' because the former is a condition "wherein the will to battle is sufficiently known" (in Doyle 1997: 114), realist actors derive their knowledge of violent conflict as a recurrent phenomenon from experience and History. The view of war as an ever-present possibility that states cannot escape gives the realist actor a pessimistic attitude and a cyclical temporal 
This is the accepted version of a forthcoming article that will be published by Sage in European Journal of International Relations: http://journals.sagepub.com/loi/ejta

Accepted version downloaded from SOAS Research Online:

outlook where "the future is the past" (Gray, 1999). ${ }^{13}$ This outlook also affects the ontology of interstate relations by marking them as rivals and potential enemies.

This, in turn, makes it prudent to invest in measures that enable states to defend/secure their 'sovereignty' in the future, thus translating the 'will to survive' into a 'will to power'. Seeing the pursuit of power, in the sense of building up military capabilities, as driven both by fear and by rational calculation is a tension in realist theorizing, which also underpins the prescription to form alliances with states one should distrust: realist actors are expected to cooperate for the purpose of balancing power, yet at the same time should be reluctant to cooperate due to the worry about 'relative gains' which "affect relative capabilities in the future" (Grieco, 1990: 45, emphasis in original). Thus, the 'ally' always remains a potential enemy. The most decisive consequence for the ontology of the realist actor, however, is that the move from seeking sovereignty to maximizing power turns 'power' into its most important attribute. The sovereign state morphs into a 'power container'. And because realists view power as relative, i.e. measured in comparison with the capabilities of other states, the ontology is comparative as well. The result is a socio-spatial image that ranks states according to their 'power' and highlights polarity, weaving a structure of hierarchy into anarchy. By holding that the most powerful states matter most, due to their ability to threaten others, the realist world is effectively reduced to a map of 'great powers' where small (in the sense of 'weak') states are little more than moving parts in shifting alignments.

\section{Liberalism}

One of the hallmarks of liberal theorizing, going back to the idea of enlightenment, is an emphasis on particular human capacities and rights, and to attribute the ability to develop and 'own' these capacities/rights to all individuals. As such, liberal subjects are progressive: they have potential for growth and the ability to reason that enables them to learn and realize their potential. Prominent here is the notion of the liberal subject as rational, usually understood as the capacity to make decisions on the basis of cost-benefit calculations and choose the option that maximizes their goals. Yet the 'rational actor' assumption by itself does not ground liberal theorizing. After all, realists use it as well and, strictly speaking, rationality is not a drive as it leaves open the goal(s) underpinning the calculation. However, distinct ontologies and drives become visible when the 'rational actor' is placed in a particular liberal account of the human condition.

Influential strands of liberal theorizing highlight that humans seek wealth, or economic gain

\footnotetext{
${ }^{13}$ Prominently captured in Mersheimer's 'back to the future' argument (Mearsheimer, 1990)
} 
This is the accepted version of a forthcoming article that will be published by Sage in European Journal of International Relations: http://journals.sagepub.com/loi/ejta

Accepted version downloaded from SOAS Research Online:

(Keohane 1984). This drive is entwined with a reading of humans situated in a socio-spatial environment marked by interdependence and openness. In this imagery, states are depicted as open 'units', with permeable borders, and as connected, with linkages reaching into domestic structures (Keohane and Nye 1989; Keohane 2002). While some liberals maintain the focus on states, it shifts the view towards the transnational. By showing connections below, above and beyond states, liberal theorizing carves out international institutions and non-state actors, whether multi-national corporations or transnational civil society-networks, as political actors. For some this merely makes anarchy more complex, yet for most theorists it depicts an entirely different socio-spatial environment captured in John Burton's cobweb model, or in the notion of globalization as a process of 'de-territorialization' and the emergence of a 'borderless world' (Burton 1972; McGrew and Held 2007; Ferguson and Jones 2002). For some, globalization is "the universal condition of world politics" (Moravcsik 2008: 234), a dynamic and progressive space marked by openness and movement and culminating in the cosmopolitan ontology of humanity as one people.

This space both forms and is formed by the liberal subject. A central element of liberal theorizing here is that actors with the freedom to move and meet (should) want to cooperate. As rational beings, they (should) know that diverse but compatible talents will allow for productive exchange and, hence, that working together is beneficial. This renders cooperation not simply a form of interaction but a primary motivation and manifests the liberal subject as a cooperative being. And as peaceful, at least towards fellow liberals: as developed in the 'democratic peace' literature, actors that are free to weigh the costs and benefits of war will choose not to fight because they calculate that the (potential) benefits of cooperation outweigh the (potential) costs of fighting wars. The crucial aspect here is the once, which points to the necessity of having a social environment in which individuals can decide freely and are able to capitalize on their common/compatible interests. In other words, liberal actors are theorized as 'peaceful' if their environment allows them to be, which for IR theorists requires a liberal order in both political (democratic) and economic (free market) terms (Doyle 1983; Owen 1994).

The progressive theme characteristic of liberal theorizing is developed through the temporal dimension. As Beate Jahn (2013: 44ff.) has shown, liberal theorists historically ground the ostensibly natural rights of individuals in the 'unspoiled' life of indigenous communities to then argue that this 'state of nature', where humans are born free and equal, is lost in the present world and needs to be regained in the future. Due to the human capacity to learn and to grow, this is presented as a veritable possibility, instilling liberal actors with an optimistic and forward-looking attitude that sees the future as a space of opportunity. However, it also 
This is the accepted version of a forthcoming article that will be published by Sage in European Journal of International Relations: http://journals.sagepub.com/loi/ejta

Accepted version downloaded from SOAS Research Online:

depicts the world as a 'not yet' fully open, where some have the freedom to interact as equals and develop their talents but others do not. It generates an image of socio-spatial hierarchy where communities are separated not so much by formal borders but by gaps in the ability to realize their potential, essentially a two-tiered world captured in familiar metaphors of 'developed' and 'underdeveloped', 'modern' and 'pre-modern', or 'free' and 'unfree' spaces. By extending the democratic peace thesis, this opens the door to a security argument that reads 'unfree' spaces, and the subjects within it, as a threat to the 'free world'. Yet these threats are not permanent. Emphasizing the potential for change and maintaining that all humans can, want to and should be free, liberal actors contemplate how disadvantaged subjects can (be assisted to) transform their environment. The answer, of course, is the expansion of spaces of liberal economic and political order, which thus becomes a primary motivation and course of action (Doyle 2008; Ikenberry 1999; Jahn 2013: Ch. 4).

This missionary action depicts the liberal actor as an intervening force, including through the use of military means, so liberal actors are not inherently peaceful. Typically, though, liberal agency is expressed in the establishment and maintenance of institutions, or "rule based orders" (Ikenberry 2001), as structures that optimize the socio-spatial and socio-temporal situatedness of political actors. Some see them as instruments for mitigating future uncertainty and foster cooperation by increasing transparency, helping avoid misunderstandings and monitoring compliance, making rational actors weigh their decisions in the 'shadow of the future' (Axelrod 1984; Jervis, 1999; Keohane and Martin, 1995). Others emphasize how institutions are used to promote liberal norms and ideas into spaces where they do not exist (Keck and Sikkink 1998; Risse et al. 1999; Jahn 2013), enabling subjects to organise their life in accordance with these norms, expecting that others will do so as well (Owen 1994). As such, institutions become part of the human condition by structuring political space and allowing subjects to act along a temporal logic of consequences, appropriateness, and possibility that reduces future uncertainty and enables them to become better and trustworthy beings. This move of stretching domestic political orders into the international is not without tensions, not least through its image of the liberal world as both free and rule-based. Yet it allows the liberal actor to wander along a spectrum from optimizing cooperation to freeing 'un-free' subjects, which accommodates both conservative (preservation of liberal order) and transformative (creation of liberal order) accounts of (inter)action. The normative element underpinning both is the combined belief in the universality of liberal norms and in progress, which gives liberal theorizing its distinct temporal outlook that favours the future. Whereas the realist subject learns from History that wars that cannot be escaped, the liberal subject can learn to avoid wars and turn enemies into friends. It 'knows' that it is possible to leave the past behind. In that sense, the liberal account 
This is the accepted version of a forthcoming article that will be published by Sage in European Journal of International Relations: http://journals.sagepub.com/loi/ejta

Accepted version downloaded from SOAS Research Online:

of the human condition as an interdependent and open space is, above all, a potentiality, which the theorist wants its actor(s) to fulfill.

\section{Postcolonialism}

Postcolonial theorizing is concerned with subjects struggling within and against a configuration marked by imperialism, placing the focus on the subordinated and disenfranchised side, the 'subaltern' (Spivak, 1988: 78). The conceptualization of this subject and its drives - seeking recognition, justice and, especially, emancipation - occurs through a reading of the condition of 'postcoloniality' (Gandhi 1998: 3). This condition encompasses the period of physical occupation and following it, when the population in question has gained formal independence yet still feels the effects of the colonial experience. The legacy of colonialism is thus an important aspect, which renders the meaning of the 'post' ambivalent. ${ }^{14}$ In IR, then, postcolonial theorizing focuses on how legacies of former colonial relationships and new forms of (usually Western) imperialism and colonialism play out in contemporary world politics with the aim to retrieve the agency of (usually non-Western) actors.

Crudely put, postcolonial theorizing develops two faces. The first shows the colonial relationship as a system of occupation, domination, discrimination and exploitation and focuses on the power the colonizer exerts over body and mind of the colonized population. The Gramscian frame, from which the concept of the subaltern stems, shows the latter as a class produced by a hegemonic system held in place by a ruling elite. This tends to be combined with the Hegelian master-slave metaphor and a depiction of the colonial configuration in two ways: (i) a unidirectional relationship where the colonizer (master) brings the colonized (slave) into existence and where the latter wants to be like the former, or (ii) a relationship in which both sides are mutually constituted and their existence intertwined. Both readings are expressed in different accounts of postcolonial space and time.

The "architecture of the colonial space" (Jabri 2013: 26ff) is an imperial structure that is both transnational in scope and exercised locally, variably conceived in 'centre-periphery' or 'huband-spoke' imagery (Nexon and Wright 2007). In its most tangible form, the power of the coloniser is expressed in the physical occupation of territory and the material organisation of space, including the violent coercion and oppression of native populations. There are two ways of reading the subaltern in this space. The first shows "a world cut in two" (Fanon 2001 [1963]: 29), which is separately inhabited by the 'settler' (coloniser) and the 'native' (subaltern) and creates corresponding binary identities. The institutions of this Manichaean structure are created and controlled by the coloniser, limiting the movement of the subaltern

\footnotetext{
${ }^{14}$ Omitting the hyphen, i.e. calling it postcolonial rather than post-colonial, is to indicate the overlap.
} 
This is the accepted version of a forthcoming article that will be published by Sage in European Journal of International Relations: http://journals.sagepub.com/loi/ejta

Accepted version downloaded from SOAS Research Online:

and restricting it to a particular space, a form of ghetto. The second reading holds that, precisely because the native/subaltern is an intrinsic part of the imperial structure, the configuration lacks a clear inside-outside distinction. The border between the space of the subaltern and that of the colonizer is blurred and their identities intertwined (Seth 2013; Rao 2013), captured in the reading of the subaltern as a 'split' or 'hybrid' subject (Bhabha 1994). In both configurations, colonial power operates also on the mind of the subaltern. It is a form of psychological colonialization (Fanon) working either through Gramscian hegemony, where the coloniser actively manipulates the worldview of the subaltern, or through Foucauldian governmentality, whereby disciplining power is practiced in a more decentralised fashion (Nandy 1983; Jabri 2013). The epistemic violence (Spivak) this inflicts is expressed, in particular, in the production of a particular temporality that (re)writes the subaltern's history and its possible future into a 'master code' of linear progress towards Western civilization. In this account, the subaltern's history appears insignificant and its only positive temporal reference point is in the future, often in the ideal of the 'Western model' of liberal-capitalist order. The postcolonial subject is labeled underdeveloped, told to aspire to and work towards this ideal, unlikely to ever reach it. It is placed in a position of eternal backwardness, separated from the West yet within the latter's temporal parameters, keeping its own temporal outlook private.

Thus far, the postcolonial subject appears as a silenced and disenfranchised being, with no independent agency. It "cannot speak" (Spivak 1988) or, rather, is not heard in the colonial configuration (Rao 2013). Yet it is this condition, which kindles emancipation and demands for justice as basic motivations and shapes their behavioral expression. Making this visible is the focus of the second face of postcolonial theorizing, infused with an attitude of defiance and the normative aim to support the subaltern's empowerment. It constitutes the postcolonial subject as an emerging political actor that can take various forms, such as a state from the Global South, a domestic protest movement, or a transnational network of activists. Crucially, these actors are shown not only as wanting to challenge and emancipate from the colonial configuration but also as capable of doing so: they resist, subvert and, to a degree, escape and transform the colonial configuration by reclaiming 'their' territorial space and gaining control of 'their' being in time, their biographical narrative. This capability emerges by channeling the experience of the colonial configuration against it and is expressed in diverse practices of “decolonialisation" (Jabri 2013).

Two broad conceptions of postcolonial agency flow from the colonial configurations outlined above. The first highlights the anti-colonial outlook of the subject, which defines itself and acts against the colonial power and the condition it finds itself in. It is an antagonistic and 
This is the accepted version of a forthcoming article that will be published by Sage in European Journal of International Relations: http://journals.sagepub.com/loi/ejta

Accepted version downloaded from SOAS Research Online:

confrontational account in which the subject seeks to recover its authentic being by reclaiming its native territory and recovering its silenced history, but also is lead by the vision of "the veritable creation of a new man" (Fanon 1963: 28). This involves abolishing the spatial and temporal zone inhabited by the colonial power and, with it, the destruction of the colonial world (Ibid. 31). Because in this account the colonial configuration is based on violence, both physical and epistemic, challenging it requires radical violent acts in return and places the postcolonial actor in "a murderous and decisive struggle" (Ibid. 48). In the course of this struggle the postcolonial subject not only becomes a violent actor but also regains selfconsciousness and, ultimately, reinvents itself as a decolonised subject. Although, as Fanon (1963: 201) concedes, the struggle leaves psychological marks, making a complete disconnect from the colonial experience impossible. In the second conception, the postcolonial subject does not see the possibility of an epistemologically pure and separate being in either space or time. While a moment of temporary separation from the colonial configuration can be achieved through 'strategic essentialism' (Spivak), emancipation is sought through rather than radically against this configuration. It is done by using the "double-consciousness" (Du Bois) and hybrid status acquired through inhabiting and experiencing 'both worlds' in its favour, using "mimicry" (Bhabha 1994) and the learned ability to navigate liminal spaces and multiple pasts and futures in creative ways. In this reading, the postcolonial subject exercises agency not by violent confrontation but by shifting meaning in a way that subverts and destabilizes the authority of the colonizer and its normative base. More than an act of resistance, it makes and takes control of its place in postcolonial space-time with the "potential to reconstitute the international" (Jabri 2104: 375).

\section{Conclusion}

Almost three decades ago, Yosef Lapid (1989: 236) celebrated the post-positivist moment as the "re-awakening of metatheoretical impulses" among IR scholars. Today it appears that one of the victims of the Third Debate has been grand theory, as modern and post-modern positions - the two sides of the 'debate' - have encouraged the shallow use of theory and the rejection of theory, respectively. 'Thinking big' in the sense of substantial theorizing combining interpretive, explanatory and normative elements seems to have been pushed to the margins. In an attempt to counter this tendency and advance a discussion over what makes a substantive theory of world politics, this article implicitly followed Lapid's suggestion that one way to channel reflexivity is "systematic reconstruction" with the aim "to order and transcend diversity without submitting a new orthodoxy" (Ibid). It tried to reconstruct the macro-foundations of grand theories by putting forward the notion of 'deep theorizing' as, basically, a philosophical grounding of agency in the conceptualization of the ontology of political actors (subjects) and their drives (basic motivations) through an account of the 
This is the accepted version of a forthcoming article that will be published by Sage in European Journal of International Relations: http://journals.sagepub.com/loi/ejta

Accepted version downloaded from SOAS Research Online:

human condition. Specifically, the article argued that arguments about (inter)actions and orders in world politics are derived from particular readings of drives/basic motivations and the constitution of the subject/actor, which are developed and entwined with a particular understanding of how 'the subject' is situated in social space and time.

The plausibility of this approach was illustrated by revisiting realist, liberal and postcolonial schools of thought. Placing postcolonialism alongside realism and liberalism was to affirm its status as a substantial alternative that fills an embarrassing blind spot in mainstream discussions about world politics. ${ }^{15}$ The intention was not and cannot be to evaluate which of the three schools is deeper, but to point to comparable meta-theoretical foundations. While this article could offer only a crude sketch of each, it conveyed a dynamic process of theorizing that generates multiple, and multifaceted, subject ontologies and a variety of drives and behavioral expressions thereof. Within these, each school presents distinct forms of political agency attempting to order and own its situatedness in space and time informed by distinct attitudes - pessimism, optimism, and defiance. Each school theorizes in a logically coherent and creative way, yet their dynamic nature also produces tensions, serving as a reminder that grand theories are not only analytically rich but also less reified than sometimes portrayed (Levine and Barder 2014).

In carving out these features and highlighting the central function of a human condition account the article not only hopes to contribute to a discussion about what theoretical depth might be. It also offers an explanation for the relevance and persistent appeal of grand theories in IR, namely their ability to ground their ontologies, explanations and prescriptions in answers to philosophical questions of what drives 'us', where and who 'we' are, and should be, in space and time. Because the answers can only ever be particular, they also are political. Deep theorizing is not simply offering an analytical window on particular actors and (inter)actions; in taking and making a perspective and charting a path through the human condition it also is political theorizing. Of course, depth should not be confused with comprehensiveness and deep theorizing can produce a quite narrow account of world politics. Yet to the extent that an account of the human condition resonates with experiences and outlooks of some people across space and time, grand theories are expressions of "pluralistic universalism" (Acharya 2014: 649). And as long as we treat them not as innate truths but as sites for debate about where and how world politics takes (or ought to take) place, they remain indispensable for our field. In this vein, the approach put forward could be fruitfully applied to other schools and individual efforts to theorize world politics, and a more careful

\footnotetext{
${ }^{15}$ Whether it is the 'non-Western' theory some are looking for is another question (Acharya 2011; Thakur 2015).
} 
This is the accepted version of a forthcoming article that will be published by Sage in European Journal of International Relations: http://journals.sagepub.com/loi/ejta

Accepted version downloaded from SOAS Research Online:

study might focus on how accounts of the human condition are shaped by the position and biography of particular authors. It could also be used to explore linkages between schools, to show where they build on or implicate each other, and where they present distinct alternatives. And, of course, it may serve as a rough guide for building a new grand theory.

\section{Literature}

Acharya, A (2011) Dialogue and Discovery: In Search of International Relations Theories Beyond the West. Millennium 39(3): 19-637

Acharya, A (2014) Global International Relations (IR) and Regional Worlds: A new Agenda for International Studies. International Studies Quarterly 58(4): 647-659.

Adler E and V Pouliot (2011) International Practices: introduction and framework. In: E. Adler E and Pouliot V (eds) International Practices. Cambridge: Cambridge University Press, pp. 3-35.

Agnew J (1994) The Territorial Trap: The Geographical Assumptions of International Relations Theory. Review of International Political Economy 1(1): 53-80.

Arendt H (1958) The Human Condition. Chicago: University of Chicago Press.

Arfi B (2012) Re-Thinking International Relations Theory via Deconstruction. London: Routledge.

Aron, R (1967) What is a Theory of International Relations. Journal of International Affairs 21(2): 185-197.

Axelrod R (1984) The Evolution of Cooperation. New York: Basic Books.

Behnke A (2001) Grand theory in the age of its impossibility: contemplations on Alexander Wendt, In: Guzzini S and Leander A (eds) Constructivism and International Relations.

London: Routledge, pp. 48-56.

Berenskoetter F (2012) The End of IR Theory As We Know It... . Disorder of Things Blog https://thedisorderofthings.com/2012/08/03/the-end-of-ir-theory-as-we-know-it/

Berenskoetter F (2014) Parameters of a National Biography. European Journal of International Relations 20(1): 262-288.

Bhabha HK (1994) The Location of Culture. London: Routledge.

Bleiker R (1997) Forget IR Theory. Alternatives 22(1): 57-85.

Bleiker R (2009) Aesthetics and World Politics, London: Palgrave.

Burchill S (2001) Introduction. In: Burchill S et al. (eds) Theories of International Relations. Basingstoke: Palgrave, pp. 1-28.

Burchill S and Linklater A (2009) Introduction. In: Burchill S and Linklater A (eds) Theories 
This is the accepted version of a forthcoming article that will be published by Sage in European Journal of International Relations: http://journals.sagepub.com/loi/ejta

Accepted version downloaded from SOAS Research Online:

of International Relations, 5th edition. London: Palgrave Macmillan

Booth K (2007) Theory of World Security. Cambridge: Cambridge University Press.

Booth K and Erskine T (Eds) (2016) International Relations Theory Today, second edition. Cambridge: Polity Press

Boucher D (1998) Political Theories of International Relations. Oxford: Oxford University Press.

Branch J (2014) The Cartographic State. Cambridge: Cambridge University Press.

Brown C (1994) 'Turtles All the Way Down': Anti-Foundationalism, Critical Theory and International Relations. Millennium 23(2): 213-236.

Brown C (2009) Structural Realism, Classical Realism and Human Nature. International Relations 23(2): 257-269.

Brown C (2013) The poverty of Grand Theory' European Journal of International Relations 19(3): 483-497.

Burton JW (1972) World Society, Cambridge: Cambridge University Press.

Buzan B, Jones C and Little R (Eds) (1993) The Logic of Anarchy. New York: Columbia University Press.

Campbell D (2007) Poststructuralism In: Dunne T et al. (eds) International Relations Theories. Oxford: Oxford University Press

Carr EH (2001 [1946]) The Twenty Year's Crisis, 1919-1939. London: Palgrave.

Chakrabarty D (2000) Provincializing Europe. Princeton: Princeton University Press.

Chernoff F (2007) Theory and Metatheory in International Relations. Palgrave Macmillan.

Cox RW (1981) Social Forces, States and World Orders: Beyond International Relations Theory. Millennium 10(?): 126-155.

Crawford NC (2009) Human Nature and World Politics: Rethinking 'Man'. International Relations 23(2): 271-288.

Deudney D (2007) Bounding Power. Princeton: Princeton University Press.

Doty RL (1997) Aporia: A Critical Exploration of the Agent-Structure Problematique in International Relations Theory. European Journal of International Relations 3(3): 365-392

Doyle MW (1983) Kant, Liberal Legacies, and Foreign Affairs. Philosophy and Public Affairs, 12 (3): 205-235 and (4): 323-353

Doyle MW (1997) Ways of War and Peace. New York: W.W. Norton \& Company.

Doyle MW (2008) Liberalism and foreign policy. In: Smith S, Hadfield A and Dunne T (eds) Foreign Policy. Oxford: Oxford University Press, pp. 49-70.

Der Derian J and Shapiro MJ (1989) International/Intertextual Relations. Lexington Books 
This is the accepted version of a forthcoming article that will be published by Sage in European Journal of International Relations: http://journals.sagepub.com/loi/ejta

Accepted version downloaded from SOAS Research Online:

Dunne T, Hansen L and Wight C (2013) The End of International Relations Theory. European Journal of International Relations 19(3): 405-425.

Du Bois WEB (1903) The Souls of Black Folk. New York: Dover Publications.

Edkins J (1999) Poststructuralism and International Relations. Lynne Rienner Publishers

Emirbayer, M and Mische A (1998) What is Agency? The American Journal of Sociology 103(4): 962-1023.

Epstein C (2013) Theorizing Agency in Hobbes's Wake: The Rational Actor, the Self or the Speaking Subject. International Organization 67(2): 286-316.

Epstein C (2014) The postcolonial perspective: an introduction. International Theory 6(2): 294-311

Fanon F (2001 [1963]) The Wretched of the Earth. London: Penguin

Ferguson YH and Jones RJB (2002) Political Space. Albany: State University of New York Press.

Finnemore M (1996) National Interests in International Society. Ithaca: Cornell University Press.

Freyberg-Inan A (2004) What Moves Man. New York: SUNY Press.

Gandhi, L (1998) Postcolonial Theory. New York: Columbia University Press.

Gray, C (1999) Clausewitz Rules, OK? The Future is the Past - With GPS. Review of International Studies 25(?): 161-82.

Grieco J M (1990) Cooperation Among Nations. Ithaca: Cornell University Press.

Guzzini S (2013) The ends of International Relations theory and modes of theorizing. European Journal of International Relations 19(3): 521-541.

Puchala, DJ (2003) Theory and History in International Relations. New York: Routledge.

Harding S (1993) Rethinking Standpoint Epistemology: What is 'Strong Objectivity'? In: Alcoff L and Potter E (eds) Feminist Epistemologies. London: Routledge, 49-82.

Harvey D (1989) The Condition of Postmodernity. Oxford: Basil Blackwell.

Held D and McGrew A (2007) Globalization Theory. Cambridge: Polity Press.

Henderson E (2013) Hidden in plain sight: racism in international relations theory. Cambridge Review of International Affairs 26(1): 71-92.

Herz JH International Politics in the Atomic Age. New York: Columbia University Press.

Hirschman AO (1986) The Passions and the Interests. Princeton: Princeton University Press.

Humphreys A (2011) The heuristic application of explanatory theories in International Relations. European Journal of International Relations 17(2): 257-277 
This is the accepted version of a forthcoming article that will be published by Sage in European Journal of International Relations: http://journals.sagepub.com/loi/ejta

Accepted version downloaded from SOAS Research Online:

Hutchings K (2008) Time and World Politics. Manchester: Manchester University Press.

Hutchings K (2011) What is orientation in thinking?: on the question of time and timeliness in cosmopolitical thought. Constellations, 18(2): 190-204.

Hobson JM (2000) The State and International Relations. Cambridge: Cambridge University Press.

Hobson JM (2012) The Eurocentric Conception of World Politics. Cambridge: Cambridge University Press.

Hoffmann S (1959) International Relations: The Long Road to Theory. World Politics 11(3): 346-377.

Hollis M and Smith S (1991) Explaining and Understanding International Relations. Oxford: Clarendon Press.

Ikenberry JG (1999) Why export democracy? The 'hidden grand strategy' of American foreign policy. The Wilson Quarterly 23(2): 56-65.

Ikenberry JG (2001) After Victory. Princeton: Princeton University Press.

Jabri V (2013) The Postcolonial Subject. London: Routledge.

Jabri V (2014) Disarming norms: postcolonial agency and the constitution of the international. International Theory 6(2): 372-390

Jacobi D and Freyberg-Inan A (eds) (2015) Human Beings in International Relations. Cambridge: Cambridge University Press.

Jahn B (2013) Liberal Internationalism. London: Palgrave Macmillan.

Jahn B (2016) Theorizing the Political Relevance of International Relations Theory. International Studies Quarterly, online first

Jorgensen KE (2010) International Relations Theory. Basingstoke: Palgrave Macmillan.

Keck M and Sikkink K (1998) Activists Beyond Borders. Ithaca: Cornell University Press.

Keohane RO (1984) After Hegemony. Princeton: Princeton University Press.

Keohane RO (1988) International Institutions: Two Approaches. International Studies Quarterly 32(4): 379-396.

Keohane RO and Martin L (1995) The Promise of Institutionalist Theory. International Security 20(?): 39-51

Keohane RO (2002) Power and Governance in a Partially Globalized World. London: Routledge.

Keohane RO and Nye JS (1989) Power and Interdependence, second edition. Glenview: Scott, Foresman and Company.

Kersting W (1996) Die politische Philosophie des Gesellschaftsvertrags. Darmstadt: Primus 
This is the accepted version of a forthcoming article that will be published by Sage in European Journal of International Relations: http://journals.sagepub.com/loi/ejta

Accepted version downloaded from SOAS Research Online:

King G, Keohane, RO and Verba S (1994) Designing Social Inquiry. Princeton: Princeton University Press.

Kratochwil, F (1982) On the notion of 'interest' in international relations. International Organization 36(1): 1-30.

Kratochwil, F (1989) Rules, Norms, and Decisions. Cambridge: Cambridge University Press.

Kuhn, TS (1996 [1962]) The Structure of Scientific Revolutions. Chicago: The University of Chicago Press.

Kurki M (2008) Causation in international relations. Cambridge: Cambridge University Press.

Lakatos I (1970) Methodology of Scientific Research Programmes. In: Lakatos I and Musgrave A (eds) Criticism and the Growth of Knowledge. Cambridge: Cambridge University Press, pp. 91-196.

Lake D (2011) Why 'Isms' Are Evil: Theory, Epistemology and Academic Sects as Impediments to Understanding and Progress. International Studies Quarterly 55(2): 465-480.

Lake D (2013) Theory is dead, long live theory: the end of Great Debates and the rise of eclecticism in International Relations. European Journal of International Relations 19(3): 567-587.

Lapid Y (1989) The third debate: On the prospects of international theory in a post-positivist era. International Studies Quarterly 33(3): 235-254

Lebow RN (2008) A Cultural Theory of International Relations. Cambridge: Cambridge University Press.

Lebow RN (2014) Constructing Cause in International Relations. Cambridge: Cambridge University Press.

Levine DJ (2012) Recovering International Relations. Oxford: Oxford University Press

Levine, DJ and Barder AD (2014) The closing of the American mind: 'American School' International Relations and the state of grand theory. European Journal of International Relations 20(4): 863-888

Linklater (1996) The Achievements of Critical Theory. In: Smith S, Booth K and Zalewski, M (eds) International Theory: positivism and beyond. Cambridge: Cambridge University Press, pp. 279-298.

Lyotard JF (1984 [1979]) The Postmodern Condition. Transl. G. Bennington and B. Massumi, Manchester University Press.

Luhmann N (1992) Beobachtungen der Moderne. Opladen: Westdeutscher Verlag.

Mearsheimer JJ (1990) Back to the Future. Instability in Europe after the Cold War. International Security 15(1): 5-56.

Mearsheimer JJ (2001) The Tragedy of Great Power Politics. New York: W. W. Norton. 
This is the accepted version of a forthcoming article that will be published by Sage in European Journal of International Relations: http://journals.sagepub.com/loi/ejta

Accepted version downloaded from SOAS Research Online:

Mearsheimer JJ and Walt SM (2013) Leaving theory behind: Why simplistic hypothesis testing is bad for International Relations. European Journal of International Relations 19(3): 427-457.

McIntosh C (2015) Theory across time: the privileging of time-less theory in international relations. International Theory 7(3): 464-500.

Moravcsik, A (2008) The New Liberalism. In: Reus Smit C and Snidal D (eds) The Oxford Handbook of International Relations. Oxford: Oxford University Press, pp. 234-254.

Morgenthau HJ (2011 [1954]) The Theoretical and Practical Importance of a Theory of International Relations. In: Guilhot N (ed) The Invention of International Relations Theory. New York: Columbia University Press, pp. 263-267.

Morgenthau HJ (1960) Politics among Nations. New York: Alfred Knopf.

Nandy A (1983) The Intimate Enemy. New Delhi: Oxford University Press.

Nexon D and Wright T (2007) What's at Stake in the American Empire Debate. American Political Science Review 101(2): 253-271.

Nicholson M (1996) The continued significance of positivism?. In Smith S, Booth K and Zalewski M (eds) International Theory: positivism and beyond. Cambridge: Cambridge University Press, pp. 128-147.

Onuf N (1989) World of Our Making. Columbia: University of South Carolina Press.

Owen JM (1994) How Liberalism Produces Democratic Peace. International Security 19(2): 87-125.

Popper K (1968) The Logic of Scientific Discovery. New York: Harper and Row.

Rao R (2013) Postcolonialism. In: Freeden M, Sargent LT and Stears M (eds) The Oxford Handbook of Political Ideologies. Oxford: Oxford University Press, pp. 271-289.

Reus-Smit, C and Snidal D (2008) Between Utopia and Reality: The Practical Discourses of International Relations. In: Reus Smit C and Snidal D (eds) The Oxford Handbook of International Relations. Oxford: Oxford University Press, pp. 3-40.

Risse T, Ropp S and Sikkink K (1999) (Eds) The Power of Human Rights. Cambridge: Cambridge University Press.

Rosenau JS (1980) Thinking Theory Thoroughly. In: Rosenau JS (eds) Scientific Study of Foreign Policy. London: Frances Pinter, pp. 19-31.

Rosenau, P (1992) Postmodernism and the Social Sciences. Princeton: Princeton University Press.

Sabaratnam, M (2011) IR in Dialogue... but Can We Change the Subjects? A Typology of Decolonising Strategies for the Study of World Politics. Millennium 39(3): 781-803.

Sabine GH (1969 [1939]) What is a Political Theory?. In: Gould JA and Thursby VV (eds) Contemporary Political Thought. New York: Holt, Rinehart and Winston, pp. 7-20.

Seth S (2013) Postcolonial Theory and International Relations. London: Routledge. 
This is the accepted version of a forthcoming article that will be published by Sage in European Journal of International Relations: http://journals.sagepub.com/loi/ejta

Accepted version downloaded from SOAS Research Online:

Shapiro I, Smith R and Masoud TR (2004) Problems and Methods in the Study of Politics. Cambridge: Cambridge University Press.

Smith, S (1996) Positivism and beyond. In: Smith S, Booth K and Zalewski M (eds) International Theory: positivism and beyond. Cambridge: Cambridge University Press, pp. $11-46$

Smith S (2004) Singing our world into existence: International Relations Theory and September 11. International Studies Quarterly 48(3): 499-516

Spivak GC (1988) 'Can the Subaltern Speak?. In Nelson C and Grossberg L (eds) Marxism and the Interpretation of Culture. Basingstoke: Macmillan, pp. 271-313.

Sylvester C (2009) Art/Museums. Boulder, CO: Paradigm Publishers.

Taliaferro JW (2000) Security Seeking Under Anarchy. International Security 25(?): 128161.

Thakur, V (2015) Africa and the Theoretical Peace in IR. International Political Sociology 9(3): 213-229.

Vasquez JA (1995) The Post-Positivist Debate: Reconstructing Scientific Enquiry and International Relations Theory After Enlightenment's Fall. In: Booth K and Smith S (eds) International Relations Theory Today. Cambridge: Polity Press, pp. 217-240.

Vitalis R (2015) White World Order, Black Power Politics. Ithaca: Cornell University Press.

Waever O (2009) Waltz's Theory of Theory. International Relations 23(2): 201-222.

Walker RBJ (1989) History and Structure in the Theory of International Relations. Millennium 18(2): 163-183.

Walker RBJ (1995) International Relations and the Concept of the Political. In: Booth K and Smith S (eds) International Relations Theory Today. Cambridge: Polity Press, pp. 306-327

Waltz K (1979) Theory of International Politics. Reading: Addison-Wesley.

Waltz K (1997) Evaluating Theories. American Political Science Review 91(?): 913-917.

Weber M (1992) Soziologie. Universalgeschichtliche Analysen. Politik, Stuttgart: Kroener.

Weber C (2010) International Relations Theory, third edition. London: Routledge.

Weber C (2015) Why is there no Queer International Theory?. European Journal of International Relations 21(1): 27-51

Weber C (2016) Queer International Relations. Oxford: Oxford University Press

Wendt A (1987) The Agent-Structure Problem in International Relations Theory. International Organization, 41(3): 335-370.

Wendt A (1998) On Constitution and Causation in International Relations. Review of International Studies 24 (special issue): 101-117. 
This is the accepted version of a forthcoming article that will be published by Sage in European Journal of International Relations: http://journals.sagepub.com/loi/ejta

Accepted version downloaded from SOAS Research Online:

Wendt A (1999) Social Theory of International Politics. Cambridge: Cambridge University Press.

Wight C (1996) Incommensurability and Cross-Paradigm Communication in International Relations Theory: What's the Frequency, Kenneth?. Millennium 25(2): 291-319.

Wight C (2006) Agents, Structures and International Relations. Cambridge: Cambridge University Press.

Wohlforth WC (2008) Realism. In: Reus Smit C and Snidal D (eds) The Oxford Handbook of International Relations. Oxford: Oxford University Press, pp. 131-149.

Wolfers A (1962) Discord and Collaboration. Baltimore: Johns Hopkins University Press.

Young, RJC (2001) Postcolonialism: A Historical Introduction. Wiley-Blackwell.

Zalewski M (1996) 'All these theories yet the bodies keep piling up': theories, theorists, theorizing. In: Smith S, Booth K and Zalewski M (eds) International Theory: positivism and beyond. Cambridge: Cambridge University Press, pp. 340-353.

Zehfuss M (2002) Constructivism in International Relations. Cambridge: Cambridge University Press. 